\title{
The tetranucleotide hypothesis: a centennial
}

\author{
István Hargittai
}

Published online: 29 July 2009

(C) Springer Science+Business Media, LLC 2009

\begin{abstract}
Phoebus Aaron Levene established the tetranucleotide hypothesis for the structure of nucleic acids in 1909 and kept refining it during the ensuing three decades of his life. To some, this hypothesis was a major obstacle in recognizing the ability of desoxyribonucleic acid of being the substance of heredity. To others, Levene's discovery was a milestone in the quest for uncovering the chemistry of life.
\end{abstract}

Keywords Phoebus Levene - Structure of nucleic acids · Tetranucleotide hypothesis

Generalizations in science are both necessary and hazardous.

Erwin Chargaff [1]

Phoebus A. Levene (1869-1940) was a prolific chemist, a pioneer in biochemistry, and the mentor (alas, rather autocratic) of generations of American biochemists. He published about 700 papers during his near-half-century

\footnotetext{
I. Hargittai $(\bowtie)$

Department of Inorganic and Analytical Chemistry and Materials Structure and Modeling Research Group of the Hungarian Academy of Sciences, Budapest University of Technology and Economics, P.O. Box 91, 1521 Budapest, Hungary e-mail: istvan.hargittai@gmail.com
}

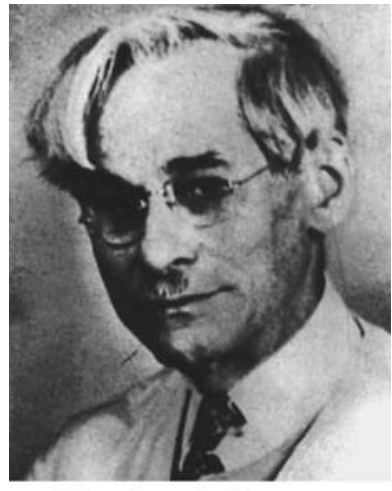

Phoebus A. Levene

career and worked with proteins, nucleic acids, carbohydrates, lipids, and vitamins. Some of his most seminal works were in the identification and understanding of biologically important carbohydrates (see, e.g., [2]). A recent review in this Journal discussed the structure of hyaluronic acid [3], and Levene's pioneering work was a significant forerunner in the understanding of the structure and physiological significance of this important polysaccharide. At the peak of his career he published an article in Science with the title "Sugars in the Service of Chemistry" [4]. He starts this article with the following statement: "Sugars are the most popular topic of chemical literature to-day." He then even claims that "the progress of civilization can be measured by the extent of the uses made of carbohydrates for constructive and destructive purposes." Today, while the great diversity and importance of carbohydrates is being recognized, few would doubt that proteins and nucleic acids have been considered the most important and, accordingly, the most popular research subjects. When Levene was embarking on his career in science at the turn of the nineteenth and twentieth 
centuries, he could have gone in either direction. At the end, he did not make a choice, at least not between carbohydrates and nucleic acids and pursued them both during his endeavors in research. In any case, he, like many others in chemical research at the time, did not recognize the extraordinary importance of nucleic acids and thereby contributed - unwittingly, of course-to the process in which the main thrust in nucleic acid research was shifting from the realm of chemistry toward biology.

This Editorial will focus on some aspects of his work in the area of nucleic acids. He did seminal research in uncovering the structure of nucleic acids and obtained his remarkable results with purely chemical techniques. His achievements often appear overshadowed by the limitation of his tetranucleotide hypothesis, which in his time was a fruitful advance but soon after his death was proved erroneous.

In order to arrive at meaningful answers, Levene, first of all, had to pose some meaningful questions. The first one concerned the relation of the yeast nucleic acid to the nucleic acids in other organisms [5]. We may as well record what was erroneous in Levene's answer to his question. He did not recognize that the compositions of nucleic acids were organism-specific and he did not recognize that in most organisms the four nucleotides are not present in equal amounts. We might as well state that his was an erroneous conclusion, which did not stem from any erroneous experiment; rather, it came from bad luck due to the imperfection of the analytical techniques of his time, which did not allow a reliable determination of the relative amounts of nucleotides in nucleic acids. It was only in the second half of the 1940s that Erwin Chargaff established the organism-specificity of nucleic acids and the special relationships among the amounts of nucleotides in any organism. One might ask how could have luck played a role in answering such an important question. The response to this question might be formulated as follows: had Chargaff studied nucleic acids from organisms in which the ratios of nucleotides were the same, he might have not come to the discovery of the so-called Chargaff rules [6-11].

Looking into Levene's painstaking studies into the composition of nucleic acids in different organisms and in different tissues of the same organism, it is seen that Levene did not take it for granted initially that the nucleotides would be in the same proportions. However, his investigations as well as those of his contemporaries could not establish reliably the differences in these proportions and the soundly established facts remained-in today's evaluation - the qualitative rather than the quantitative composition of the nucleic acid. Rather than scolding Levene for his failure of establishing the quantitative proportions of nucleotides, we might as well briefly review the tremendous progress he made in researching the structure of nucleic acids. In the words of the science historian Robert Olby, "this great chemist lifted the subject out of its confusion and extricated the nucleic acids from their conceptual entanglement with the proteins" [12].

In studying the yeast nucleic acid, he established its empirical formula as $\mathrm{C}_{38} \mathrm{H}_{50} \mathrm{O}_{29} \mathrm{~N}_{15} \mathrm{P}_{4}$ and he found the four bases, guanine, adenine, cytosine, and uracil—it was a ribonucleic acid, RNA-in equimolecular proportions. He identified the sugar content as pentose and determined the presence of phosphoric acid. He could not determine the mode of linkage between the individual nucleotides; nevertheless, suggested a constitutional formula depicted in Fig. 1.

Levene identified the four bases by their empirical formulas and was mistaken only in the formula of cytosine and by a single hydrogen atom only. This was the beginning of the tetranucleotide hypothesis, which Levene considered less and less to be merely a hypothesis during the following decades as he kept improving and adding evidence to his previous findings.

A few years after he published his results on the yeast nucleic acid, Levene, together with W. A. Jacobs reported the results of their investigation of thymus nucleic acid [13]. This was a desoxyribonucleic acid, DNA, so thymine appeared in it in place of uracil. Again, the mode of linkage between the nucleotides was not cleared up. In the ensuing years, Levene alone or with associates published further papers on the structures of yeast and thymus nucleic acids. There were new results in some papers, in others the impression is that he felt the necessity of communicating further reports to have an opportunity to fend off criticism

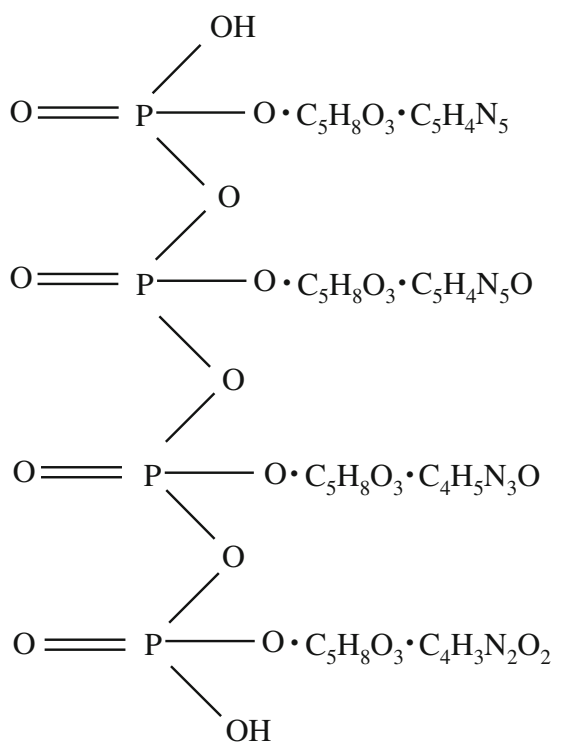

Fig. 1 Hypothetical structural formula of the tetranucleotide of the nucleic acid of yeast as proposed by Levene in 1909 (cf. Ref. 5) 
by others of his previous findings. In the early papers Levene stated that the mode of linkage between the nucleotides was not yet known. Eventually, he thought he had established it successfully and identified it as phosphodiester linkage, but this was not correct [14]. Soon, there was another road post when Levene reported success in isolating the nucleotides of yeast nucleic acid in crystalline form [15]. In 1921, Levene reported his latest results on the structure of thymus nucleic acid and established all four bases with correct empirical and structural formulas, except for the mode of their linkage [16]. In one of his last papers on nucleic acids he was still struggling with finding the correct mode of linkage between the nucleotides [17].

To assess the importance of Levene's contribution to the structural chemistry of nucleic acids is instructive to compare the state of affairs at the end of the nineteenth century and the realm of knowledge he helped to create by 1940. When he started his work in this area, it was only known that the nucleic acids were composed of phosphoric acid and nitrogenous and non-nitrogenous substances. By the time he was leaving the scene, the nature of nucleotides was uncovered and all five kinds were identified. This is why his obituary noted that "As a result of Levene's work we have an exact concept of the structures of these huge molecules, probably the most complex biological materials whose architectural picture has been reconstructed" [18]. This statement in his obituary by one of his former associates and the co-author of his monograph about nucleic acids [19], L. W. Bass points to perhaps Levene's most important achievement in the field, viz., that the nucleic acids are linear chains rather than cyclic molecules of only four building units. In this linear chain the phosphate estersugar backbone links the purine and pyrimidine bases as illustrated in Fig. 2.

Why is it then that the tetranucleotide hypothesis has been viewed often so negatively? What happened was that the hypothesis at some point became a dogma. Today it is

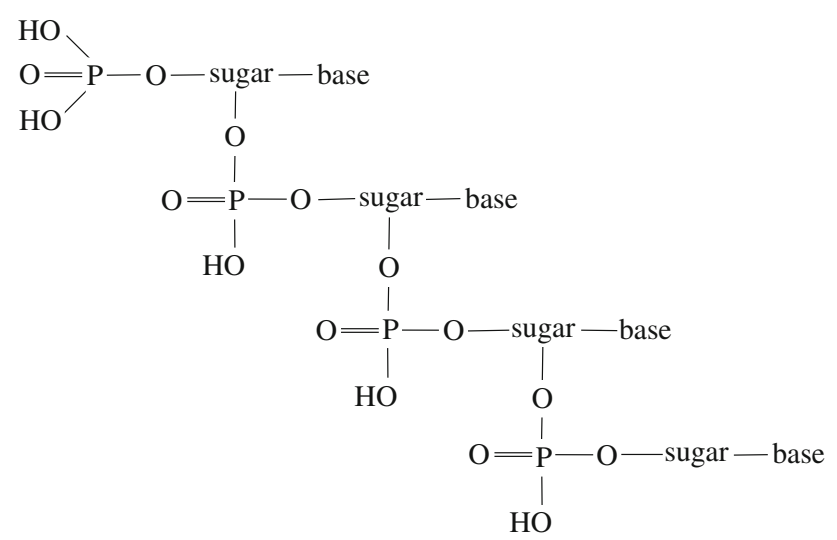

Fig. 2 Levene's linear-chain structure of nucleic acids in which phosphate ester-sugar backbone links the purine and pyrimidine bases difficult to assess whether Levene's authoritative approach to science or the enormous respect his contemporaries wielded toward him was the determining factor in this; perhaps the combination of the two. In any case, looking back, at some point the tetranucleotide hypothesis started playing the role of hindering progress and much contributed to the view that nucleic acids were "dull" and even "idiotic" molecules, and the attention in looking for the substance of heredity was turning back toward the proteins.

It might even be stated that the tetranucleotide hypothesis started living its own life to some extent independent of its original author. Quoting again Olby, "The tetranucleotide theory offers a remarkable example of those paradigms which start off as working hypotheses in an illdefined field: tools with which to open up a subject. They are successful and become entrenched so firmly that a revolution is required to dislodge them [20]". This happened in this case, too. The hypothesis did not survive Levene by long. Oswald Avery and his associates established soon, in 1944 [21] that the substance of heredity was DNA. Within a decade then the double helix structure provided the most beautiful evidence for the replication mechanism [22]. The tetranucleotide hypothesis became obsolete, because it was realized that a dull structure in which a four-member unit is being repeated could not carry the plethora of information that must be involved in heredity. This should not though diminish the significance of Levene's pioneering work in the development that greatly contributed to where molecular biology in particular and genetics in general are.

At the same time issuing a caveat seems to be warranted. Levene's tetranucleotide hypothesis did not spring up from nothing. It was a natural development at the time in the field of nucleic acid research to which many scientists had contributed. He was the most conspicuous among them as far as the tetranucleotide hypothesis was concerned, but by far not the only one. As we look back to events increasingly removed in time, there is a tendency to single out a few individuals and ignore many others. Yet science is a collective exercise and it is not fair toward Levene and neither to his peers to attribute all the merits and shortcomings in connection with the early stage of nucleic acid research to him alone. Nonetheless, he has remained an outstanding figure in this segment of science history.

At this point a brief biographical sketch of Phoebus Levene may be instructive. He was born on February 25, 1869, in Sagor, then, Russia, now, Lithuania. He was brought up in St. Petersburg and attended the Imperial Medical Academy. This was a strong school with famous professors at one time or another, including Alexander P. Borodin (1833-1887), the organic chemist composer, and Ivan P. Pavlov (1849-1936), the Nobel laureate (1904) physiologist. It was a rare exception that the Jewish Levene 
was admitted to enroll; he excelled in his studies. The growing anti-Semitism in Russia forced the Levene family to emigrate to the United States in 1891. Levene was 22 years old at the time and had not yet completed his medical studies. He left with his family, but soon returned for a short while to St. Petersburg and finished his examination. Back in the United States, the young medical doctor passed the necessary examinations in order to practice medicine in America, and was licensed to do so in New York, which he was doing until 1896.

Levene received the first taste of doing research in St. Petersburg where Borodin's son-in-law, the organic chemistry professor A. P. Dianin let him work in his laboratory. Already a medical doctor, Levene decided to continue his chemistry studies in the School of Mines of Columbia University and carry out research simultaneously in the laboratory of Professor J. J. Curtis at the College of Physicians and Surgeons of Columbia University. In 1896, he was appointed to a position in physiological chemistry at the Pathological Institute of the New York State Hospitals. He met misfortune when he was diagnosed with tuberculosis and spent about 2 years recuperating. His friendships and professional contacts originating from Saranac Lake, while he was there as a patient, lasted a lifetime. It was also at Saranac Lake where he met Anna M. Erickson who became his wife. At some time he worked at the Saranac Laboratory for the Study of Tuberculosis.

From 1905, he was an associate at the recently organized Rockefeller Institute for Medical Research, which remained his venue of activities for the rest of his life. The only interruptions were his study trips to Europe where he gained valuable experience in advanced research in Swiss and especially German laboratories, including Albrecht Kossel's at the University of Marburg and Emil Fischer's at the University of Berlin. Levene was a modern scientist in the sense of his international interactions, the breadth of his scientific and cultural interests, and his efforts of incorporating the latest technical advances in his research. He was fascinated by his field of research and his enthusiasm was contagious.

His research accomplishments were amply recognized by his peers and he earned numerous awards and recognition. He was member of the National Academy of Sciences of the USA and a number of other prestigious American and foreign learned societies. The Chicago
Section of the American Chemical Society awarded his with its Willard Gibbs Medal and the New York Section with its William H. Nichols Medal. Most of the best biochemists at one time in the United States could claim a place on Levene's science genealogical tree as his pupil or pupil of his pupils. Perhaps, this was his most important legacy.

The full list of Levene's publications can be found in his Biographical memoir [23].

Acknowledgments Our research is being supported in part by the Hungarian Scientific Research Foundation (OTKA Nos. K60365 and T046183). This contribution was prepared during a visit at the Matrix Biology Institute (MBI) in Edgewater, New Jersey, supported by a generous travel fellowship from the MBI.

\section{References}

1. Chargaff E (1950) Experiencia 6(201-209):208

2. Levene PA (1925) Hexosamines and mucoproteins, Longmans, Green and Co

3. Hargittai I, Hargittai M (2008) Struct Chem 19:697-717

4. Levene PA (1931) Science 73:459-462

5. Levene PA (1909) Biochemische Zeitschrift 17:120-131

6. Chargaff E, Vischer EM, Doniger R, Green C, Misani F (1949) J Biol Chem 177:405-416

7. Chargaff E, Zamenhof S, Green C (1950) Nature 165:756-757

8. Chargaff E (1950) Experiencia 6:201-209

9. Zamenhof S, Brawermann G, Chargaff E (1952) Biochim Biophys Acta 9:402-405

10. Chargaff E (1978) Heraclitean fire: sketches from a life before nature. Rockefeller University Press, New York

11. Hargittai I (2005) Struct Chem 16:455-456

12. Olby R (1994) The path to the double helix: the discovery of DNA. Dover Publications, New York, p 73

13. Levene PA, Jacobs WA (1912) J Biol Chem 12:411-420

14. Levene PA (1919) J Biol Chem 40:415-424

15. Levene PA (1920) J Biol Chem 41:483-492

16. Levene PA, London ES (1929) J Biol Chem 83:793-802

17. Stuart Tipson R, Levene PA (1939) J Biol Chem 127:105-110

18. Bass LW (1940) Science 92:394-395

19. Levene PA, Bass LW (1931) Nucleic acids, American chemical society monograph series, vol 56. The Chemical Catalog Co, New York

20. Olby R (1994) The path to the double helix: the discovery of DNA. Dover Publications, New York, p 74

21. Avery OT, MacLeod C, McCarty C (1944) J Exp Med 79: 137-158

22. Watson JD, Crick FHC (1953) Nature 171:737-738

23. Van Slyke DD, Jacobs WA (1945) Biographical memoirs, vol 23. National Academy of Sciences of the USA, Washington, DC, pp 73-126 